\title{
Proposed Production Layout Using Total Closeness Rating (Tcr) Method and Corelap Algorithm in Cv. Faris Collections
}

\section{Usulan Layout Produksi dengan Menggunakan Metode Total Closeness Rating (Tcr) Dan Algoritma Corelap di Cv. Faris Collections}

\author{
Muhammad Rizky Fauzi ${ }^{1}$, Athika Sidhi Cahyana ${ }^{2}$ \\ rizkyfauzix97@gmail.com ${ }^{1)}$, athikasidhi@umsida.ac.id ${ }^{2)}$
}

Program Studi Teknik Industri, Universitas Muhammadiyah Sidoarjo, Indonesia

\begin{abstract}
Abstrack. Unplanned layout of the facility and not paying attention to the distance will be able to experience an increase in time during the production process. From the results of observations that have been made at CV. Faris Collections needs to improve the facility layout in department $E$, namely the grouping of fabrics, due to frequent piling up of fabrics. Lack of utilization of area and distance of material transfer that is too long for department I, namely cloth embroidery. This proposed layout planning uses the TCR method, which is the calculation of the closest associated distance to each production department, which is described in the ARC which requires the relationship between each activity in the area of production so that it fully refers to the TCR calculation results. This planning also uses the CORELAP Algorithm in order to obtain a proposed layout plan that is able to convert qualitative value data into quantitative data. The results of the CORELAP Algorithm are the main basis for knowing the initial lay-out coordinates and the proposed layout, and the coordinate values will be entered into the WinQSB software to determine the level of efficiency. The efficiency level of the CORELAP Algorithm is 9\%, and the efficiency of changes between departmental distances in the initial layout and proposed layout is $18 \%$.
\end{abstract}

Keyword - Facility Layout; Total Closeness Rating; Activity Reletionship Chart; CORELAP

\begin{abstract}
Abstrak. Tata letak fasilitas yang kurang terencana dan tidak meperhatikan jarak akan dapat mengalami peningkatan waktu saat proses produksi. Dari hasil pengamatan yang sudah dilakukan di CV. Faris Collections perlunya perbaikan pada tata letak fasilitas pada departemen E yaitu Pengelompokan kain, karena terjadi penumpukan kain yang sering. Kurangnya pemanfaatan area dan jarak perpindahan material yang terlalu panjang untuk ke departemen I yaitu Bordir kain. Perencanaan layout usulan ini menggunakan metode TCR yaitu perhitungan dari jarak keterkaitan terdekat pada setiap departemen produksi, yang digambarkan dalam ARC yang membutuhkan jarak keterkaitan hubungan setiap aktivitas pada luas area produksi sehingga mengacu penuh pada hasil perhitungan TCR. Pada perencanaan ini juga menggunakan Algoritma CORELAP agar mendapat layout plan usulan yang mampu merubah data nilai kualitatif menjadi data kuantitatif. Hasil dari algoritma corelap ini yang menjadi dasar utama untuk mengetahui koordinat layout awal dan layout usulan, dan nilai koordinat tersebut akan masukkan kedalam software winqsb untuk mengetahui tingkat efesiensi. tingkat efesiensi dari algoritma corelap sebesar 9\%, dan untuk efesiensi pada perubahan antar jarak departemen pada layout awal dan layout usulan sebesar $18 \%$.
\end{abstract}

Kata Kunci - Tata Letak Fasilitas; Total Closeness Rating; Activity Reletionship Chart; Algoritma Corelap.

\section{Pendahuluan}

Tata letak fasilitas yang kurang terencana dan tidak meperhatikan jarak pada saat material berpindah akan dapat menimbulkan masalah pada saat proses produksi dan akan mengalami peningkatan waktu saat proses produksi, pada CV. Faris Collections merupakan manufaktur yang bergerak pada bidang konveksi dalam pembuatan kaos, bordir, dan seragam sekolah. Pada CV. Faris Collections terdapat 13 departemen kerja yaitu departemen yang mana ada gudang bahan baku, pengemalan, potong kain, potong kerah, pengelompokkan kain, obras kain, jahit kain, rak benang, bordir, pengelompokkan kain, setrika \& packaging, gudang packaging, dan administrasi. Yang mana departemen tersebut merupakan proses untuk membuat baju, kaos, dan seragam praktek. 
Hal ini yang menjadi dasar utama untuk memberikan perbaikan layout usulan perbaikan pada CV. Faris Collections yang mampu untuk dapat mengoptimalkan hasil produksi yang lebih, dengan cara memberikan usulan aliran proses area produksi yang baik dengan aliran proses area produksi sebelumnya. Pada perancangan produksi ini dilakukan pada setiap departemen produksi, pada perancangan tata letak fasilitas ini menggunakan metode Total Closeness Rating (TCR) dan Algoritma CORELAP.

Perencanaan layout usulan ini menggunakan Total Closeness Rating (TCR) yaitu perhitungan dari jarak keterkaitan terdekat pada setiap departemen produksi, yang digambarkan dalam Activity Relationship Chart (ARC) yang membutuhkan jarak keterkaitan hubungan setiap aktivitas pada luas area produksi sehingga dalam menempatkan fasilitasnya mengacu penuh pada hasil perhitungan TCR. Pada perencanaan ini juga menggunakan algoritma Computerized Relationship Layout Planning (CORELAP) agar mendapat layout plan usulan yang mampu merubah data nilai kualitatif menjadi data kuantitatif, yang membutuhkan data hasil dari jarak kedekatan TCR dan data diagram yang didapat dari ARC.

\section{METODE}

\section{A. Konveksi}

Pada industri konveksi pakaian merupakan manufaktur yang dibuat secara massal, konveksi dapat dibilang industri kecil yang menenggah skala rumah tangga yang menghasilkan pakaian jadi seperti pakaian anak-anak, pakaian pria dewasa, pakaian wanita dewasa, dan pakaian seragam praktek sekolah. Untuk dapat membangun bisnis usaha konveksi anda dapat membuka dengan skala rumahan yang tidak harus membangun seperti pabrik Garmen (Ismanto, 2018).

\section{B. Perancangan tata letak fasilitas}

Tata letak fasilitas dibuat untuk dapat menggambarkan proses dalam susunan menjadi efesien dan efektif yang mampu meminimumkan perpindahan barang, tata letak fasilitas merupakan optimasi operasi yang diciptakan untuk sistem produksi sehingga nilai yang akan dihasilkan akan maksimal (Apple, 1990).

\section{Perpindahan Bahan Material}

Hal yang penting untuk diperhatikan tata letak fasilitas adalah panjangnya jarak transportasi perpindahan material dari satu departemen menuju ke departemen berkaitan, melihat kondisi tersebut perlu melakukan usulan alternatif layout yang mampu memiliki momen perpindahan yang minimum. Sehingga ongkos material handling dapat ditekan untuk biaya perpindahan yang berlebih (Amalia, 2017).

Activity Relationship Chart

Activity Relationship Chart (ARC) merupakan peta keterkaitan hubungan yaitu derajat hubungan kegiatan untuk dapat_merencanakan tingkat hubungan dengan aktivitas yang tejadi pada area satu dan area lainnya. Manfaat ARC adalah untuk sebagai mengetahui proses aliran kerja manakah yang memiliki keterkaitan yang dianggap penting. Sehingga perlu diletakkan berdekatan untuk mendukung kelancaran proses aktivitas produksi (Rosyidi, 2018).

Tabel 2.1 Derajat Hubungan Kedekatan

\begin{tabular}{clc}
\hline Nilai & \multicolumn{1}{c}{ Deskripsi } & Kode Warna \\
\hline A & Mutlak untuk di dektkan & Merah \\
E & Sangat penting di dekatkan & Oranye \\
I & Penting untuk dapat didekatkan & Hijau \\
O & Biasa atau cukup & Biru \\
U & Tidak penting didekatkan & Tidak ada warna \\
X & Tidak dikehendaki berdekatan & Coklat \\
\hline
\end{tabular}

Tabel 2.2 Kode dan Deskripsi Alasan

\begin{tabular}{cl}
\hline Kode Alasan & \multicolumn{1}{c}{ Deskripsi Alasan } \\
\hline 1 & Untuk aliran produksi kerja \\
2 & Aliran material handling \\
3 & Menggunakan tenaga kerja yang sama \\
4 & Sumber kontaminasi (bising, bau, debu, kotor) \\
5 & Keselamatan dan kenyamanan pekerja \\
6 & Tidak ada hubungan kerja
\end{tabular}


Procedia of Engineering and Life Science Vol. 1. No. 2 June 2021

Seminar Nasional \& Call Paper Fakultas Sains dan Teknologi (SENASAINS 2nd)

Universitas Muhammadiyah Sidoarjo

$\frac{7 \quad \text { Dapat menggunakan alat sebagai perantara }}{\text { Sumber: (Wignjosoebroto, 1996). }}$

Pembuatan Activity Relationship Chart merupakan data yang diambil dari aliran bahan pada saat proses produksi, dan u ntuk penentuan ukuran pada setiap ruang disesuaikan pada luas area yang ada dan kebutuhan bahan pada ruang tersebut. Dengan adanya pengaturan pada pendekatan setiap departemen kerja kegiatan produksi berjalan efektif dan efesien (Kumalasari, 2018).

\section{From to chart}

From to chart atau sering disebut dengan Travel Chart merupakan cara atau teknik konvensional untuk digunakan dalam perencanaan tata letak fasilitas dan juga dapat mengetahui perpindahan bahan material, From to chart pada dasarnya merupakan pembaruan dari mileage chart yang umum dijumpai pada suatu peta perjalan (road map). Angka yang terdapat pada FTC akan dapat menunjukkan total dari berat beban yang seharusnya dipindahkan, dan jarak perpindahan (Wingjosoebroto, 1996).

\section{E. Total closeness rating}

Dilakukan perhitungan pada TCR dengan cara mengkonversi pada setiap derajat kedekatan. Untuk dapat mendapatkan nilai TCR dengan memperhatikan hubungan keterkaitan pada bagan ARC dari departemen satu dengan lainnya, departemen yang sudah dikonversi untuk tingkat kedekatan lalu dilakukan total penjumlahan pada nilai TCR.

Pada penyusunan pada setiap departemen harus memiliki nilai total TCR terbesar, apabila menemukan dua departemen dengan nilai yang sama besarnya. Maka pemilihan departemen harus memiliki tingkat kedekatan hubungan $\mathrm{A}=5$ lebih banyak, apabila tidak ada maka departemen yang memiliki tingkat hubungan yang lain seperti $\mathrm{E}=4, \mathrm{I}=3, \mathrm{O}=2$, dan $\mathrm{U}=1$ sedangkan pada huruf $\mathrm{X}=0$ (Setiawan, 2017).

\section{F. Algoritma CORELAP}

Total Closeness Rating merupakan bentuk langkah awal untuk dapat menghitung CORELAP, karena Total Closeness Rating lokasi atau departemen yang akan diletakkan paling utama merupakan TCR yang memiliki nilai paling terbesarMetode CORELAP merupakan aktivitas-aktivitas yang menghubungkan secara berpasangan sehingga semua aktivitas akan dengan mudah untuk mengetahui tingkat hubungan kedekatannya (Nicholas, 2018).

Untuk penyusunan pengolahan nilai data dengan Algoritma CORELAP didasarkan pada perhitungan dari hubungan derajat kedekatan yaitu ARC, karena nilai dari ARC berfungsi untuk dapat melihat derajat hubungan pada setiap departemen yang sudah ditentukan dari awal. Kemudian langkah selanjutnya melakukan perhitungan jumlah total hubungan kedekatan atau TCR, dari hasil nilai total TCR tersebut yang merupakan perhitungan untuk dapat menentukan dan memilih penempatan awal pada departemen kerja pada perusahaan (Tarigan, 2019).

Berikut ini merupakan langkah untuk pengolahan data dengan menggunakan metode CORELAP (Tompkins, 1996). Sebagai berikut ini:

1. Hitung Total Closeness Rating (TCR) pada tiap-tiap departemen

Untuk mendapatkan Nilai TCR, jumlahkan bobot nilai kedekatan pada setiap departemen yang dimana nilai tersebut didapat dari ARC dan FTC, akan mendapatkan nilai TCR pada tiap-tiap depertemen.

2. Pada tahap selanjutnya, pilih salah departemen dengan nilai TCR maksimum untuk diletakkan pertama pada Block layout.

3. Apabila terdapat nilai TCR yang sama, pilih salah satu yang memiliki luasan yang lebih besar. Dan apabila luasan departemen sama maka pilih departemen mana yang lebih dibutuhkan pertema kali pada proses tersebut.

4. Apabila suatu departemen telah dipilih, tentukan penempatannya bedasarkan Placing Rating, yang merupakan weight closeness rating (pembobotan) pada departemen yang telah masuk maupun departemen yang akan masuk. Dengan peletakannya berlawanan arah dengan jarum jam. 
Procedia of Engineering and Life Science Vol. 1. No. 2 June 2021

Seminar Nasional \& Call Paper Fakultas Sains dan Teknologi (SENASAINS 2nd)

Universitas Muhammadiyah Sidoarjo

\section{Hasil dan Pembahasan}

\section{A. Area produksi CV. Faris collections}

Block layout awal merupakan keadaan awal layout pada perusahaan sebelum adanya perubahan layout pada lantai area produksi. Block layout awal antara lain terdiri dari luas lantai produksi pada setiap departemen dan lama waktu kegiatan proses produksi pada setiap departemen di CV. Faris Collections. Pada berikut ini merupakan kode yang ada departemen yang ada di CV. Faris Collections seperti tabel 3.1 Luas Area Lantai Produksi.

Tabel 3.1 Luas Area Lantai Produksi

\begin{tabular}{cccccc}
\hline Kode & Departemen Kerja & Banyaknya /Jumlah & Panjang $(\mathbf{M})$ & Lebar $(\mathbf{M})$ & Luas $_{\left(\mathbf{m}^{\mathbf{2}}\right)}$ \\
\hline A & Gudang Bahan Baku & 1 & 7 & 4 & 29,4 \\
B & Pengemalan & 2 & 6 & 3,6 & 21,6 \\
C & Potong kain & 2 & 6 & 3,6 & 21,6 \\
D & Potong Kerah & 1 & 2,7 & 1,2 & 3,2 \\
E & Pengelompokan Kain & 1 & 5,4 & 3 & 16,2 \\
F & Obras Kain & 2 & 2,2 & 1,8 & 3,96 \\
G & Jahit Kain & 2 & 2,2 & 1,8 & 3,96 \\
H & Rak Benang & 1 & 2,1 & 0,6 & 1,2 \\
I & Bordir & 2 & 13,2 & 4,8 & 63,3 \\
J & Pengeplongan Kancing & 1 & 1,2 & 0,9 & 1,0 \\
K & Administrasi & 1 & 1,8 & 1,2 & 2,1 \\
L & Gudang Packaging & 1 & 3,3 & 2,4 & 7,9 \\
M & Setrika \& Packaging & 1 & 2,3 & 3,3 & 7,5 \\
& & Total & & & 182,92 \\
\hline
\end{tabular}

Luas area lantai produksi digunakan untuk dapat mencari total dari luas area ruang produksi, yang dibutuhkan sebagai proses produksi pembuatan pakaian. Pada produksi baju, seragam dan lainnya yang memiliki tahapan yang mimiliki banyak tahapan proses panjang untuk dapat membuat sebuah pakaian jadi. Pada CV. Faris Collections memiliki total luas keseluruhan $182.92 \mathrm{~m}^{\wedge} 2$, Dari beberapa luas area lantai produksi di atas yang memiliki luas area terbesar yaitu departemen I dengan luas area 63,3 $\mathrm{m}^{\wedge} 2$. Untuk layout awal dapat dilihat pada gambar 3.1 berikut ini.

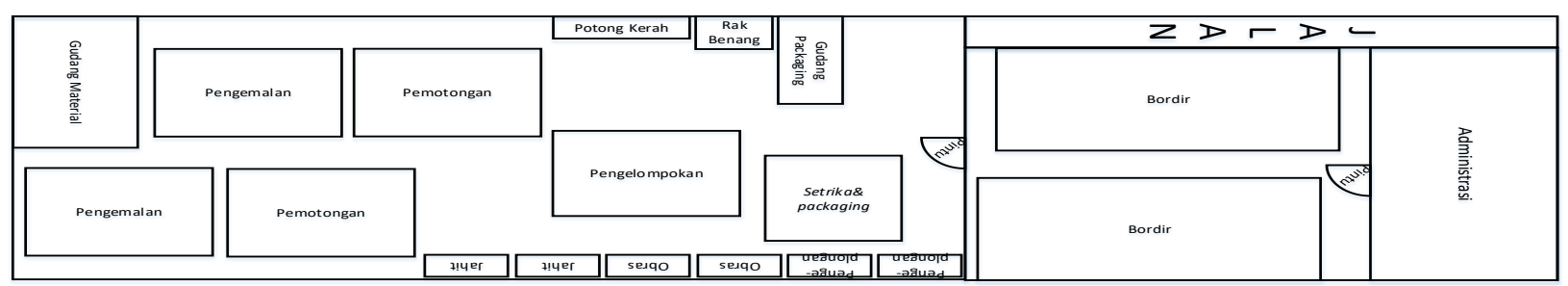

Gambar 3.1 layout awal pada CV. Faris Collections

\section{Jarak Kedekatan Antar Departemen}

Jarak antar departemen merupakan jarak yang selalu berterkaitan dengan departemen lain, untuk dapat melakukan perpindahan bahan atau material yang akan di proses. Pada berikut ini merupakan jarak antar departemen yang ada pada CV. Faris Collections yang dapat di lihat pada tabel 4.3 Jarak Kedekatan Antar Departemen Lantai.

Tabel 3.2 Jarak Kedekatan Antar Departemen Lantai Produksi

\begin{tabular}{clc}
\hline Kode & \multicolumn{1}{c}{ Departemen } & \multicolumn{1}{c}{ Jarak (m) } \\
\hline A-B & Proses inspeksi pemilihan kain roll yang akan di desain sesuai dengan permintaan konsumen & 1.5 \\
B-C & Setelah proses desain kain lalu akan dilanjutkan dengan proses potong kain yang sesuai desain yang telah diukur & 1.3 \\
C-D & Setelah pemotongan kain lalu memerlukan potongan kerah untuk bagian atas kemeja & 1 \\
& Setelah pemotongan kerah selesai, lalu melakukan penyortiran untuk mempermudah pengelompompokkan pada tiap-tiap & 2.6 \\
& bagian &
\end{tabular}


E-F Setelah melakukan inspeksi dan pengelompokan pada setiap bagain lalu akan dilakukan obras $\quad 1.5$

F-G Proses obras lalu aka menuju proses jahit kain untuk dapat menyatukan tiap bagian $\quad 1.2$

$\begin{array}{ll}\text { G-H } \quad \text { Untuk memilih penggunaan benang jahit yang cocok dengan bagian tepi kain } & 6.3\end{array}$

H-I Pemilihan benang berdasarkan desain dan warna yang diperlukan $\quad 4.3$

I-J Setalah pakaian telah dibordir akan dilajutkan dengan pengeplongan kain untuk kancing 2.7

J-K Setelah selesai melakukan pengeplongan pada baju, selanjutnya segera memberitahukan pada administrasi untuk pemberian 7.2 tanggal pengambilan.

$\begin{array}{lll}\text { K-L Administrasi memberikan tanda yang berupa alamat dan tempat pada setiap pakaian yang telah selesai } & 6.7\end{array}$

L-M Sebelum pakaian dimasukkan digudang packaging terlebih dahulu disetrikan dan dikemas 3.8

Total

\section{B. Activity reletionship chart}

Activity reletionship chart merupakan metode untuk dapat menentukan besar kecil nilai yang digunakan untuk keterkaitan kedekatan dari masing-masing antar departemen dengan depertemen lain. Pada berikut ini adalah Activity Reletionship Chart pada proses produksi pembuatan pakaian seperti gambar 3.2 Activity Reletionship Chart Produksi Pakaian

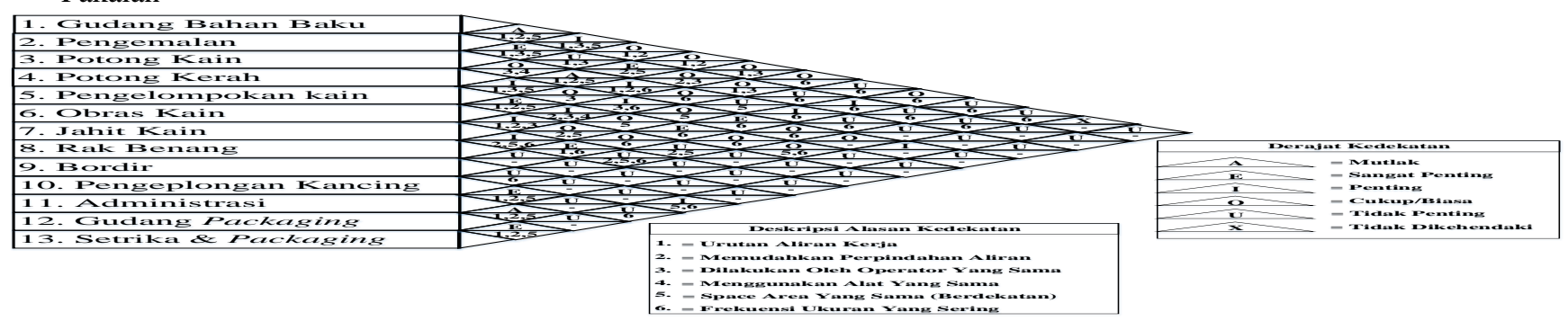

Gambar 3.2 Activity Reletionship Chart

Dari Activity Reletionship Chart diatas dapat diketahui, bahwa derajat kedekatan memiliki fungsi untuk dapat mengetahui proses perpindahan material/barang pada tiap-tiap departemen di CV. Faris Collections. Dan Activity Reletionship Chart (ARC) berikut ini menghasilkan kedekatan hubungan yang beragam dari mutlak (A) sampai tidak diharapkan $(\mathrm{X})$.

Pemberian kode huruf serta warna pada tiap departemen diatas memiliki alasan nya pada masing-masing departemen, yang dapat dilihat pada tabel 4.3 Hubungan Kedekatan ARC Antar Fasilitas.

Tabel 3.3 Hubungan Kedekatan ARC Antar Fasilitas

\begin{tabular}{|c|c|c|c|c|}
\hline NO & $\begin{array}{c}\text { Kode } \\
\text { Alasan }\end{array}$ & $\begin{array}{c}\text { Kode } \\
\text { Warna }\end{array}$ & $\begin{array}{l}\text { Hubungan } \\
\text { Kedekatan }\end{array}$ & Keterangan \\
\hline 1 & $1,2,5$ & A & Mutlak & $\begin{array}{l}\text { Contohnya pada departemen Gudang dengan Pengemalan. Jarak antar departemen adalah } \\
\text { mutlak dan harus saling berdekatan }(\leq 2 \mathrm{~m}) \text {. Hal ini dikarenakan pada kedua departemen } \\
\text { tersebut memiliki hubungan yang erat dan penggunaan space area dalam kegiatan kerja } \\
\text { dan peralatan yang digunakan. Apabila kedua departemen ini memiliki jarak yang jauh, } \\
\text { maka akan dapat menyebabkan kurangnya produkstivitas kerja. }\end{array}$ \\
\hline 2 & 1,6 & $\mathrm{E}$ & $\begin{array}{l}\text { Sangat } \\
\text { Penting }\end{array}$ & $\begin{array}{l}\text { Contohnya pada departemen Pengelompokan kain dan Obras kain. Hubungan keduanya } \\
\text { menjadi sangat penting dikarenakan terdapat urutan proses produksi secara langsung pada } \\
\text { kedua departemen tersebut. Frekuensi pergerakan pekerja sangatlah tinggi dikarenakan } \\
\text { penggunaan operator/tenaga kerja yang sama. Oleh sebab itu, apabila kedua departemen } \\
\text { ini berjauhan }(\leq 3 \mathrm{~m}) \text { maka akan mengakibatkan kurangnya efesiensi produktivitas. }\end{array}$ \\
\hline 3 & $1,3,5$ & I & Penting & $\begin{array}{l}\text { Contohnya Potong Kerah dan Pengelompokkan Kain yang menggunakan space area yang } \\
\text { berdekatan yaitu }(\leq 1 \mathrm{~m}) \text { dan memiliki urutan aliran kerja secara langsung. Sehingga } \\
\text { hubungan kedunya ini adalah penting. }\end{array}$ \\
\hline 4 & $1,2,5,6$ & $\mathrm{O}$ & Biasa & $\begin{array}{l}\text { Jarak hubungan pada Obras Kain dan Jahit Kain bisa dikatagorikan cukup/biasa, yang } \\
\text { disarankan jarak pada keduanya tidak terlalu jauh maupun berdekatan dalam penggunaan } \\
\text { space area. }\end{array}$ \\
\hline 5 & - & $\mathrm{U}$ & $\begin{array}{c}\text { Tidak } \\
\text { Diperlukan }\end{array}$ & $\begin{array}{l}\text { Departemen yang dapat dikatagorikan tidak diperlukan ini, memiliki alasan yang kuat } \\
\text { untuk saling berdekatan. Contohnya Mesin Bordir dengan Rak benang yang keduanya } \\
\text { sangatlah fleksibel, yang artinya tidak terikat satu dengan yang lain. }\end{array}$ \\
\hline
\end{tabular}


Procedia of Engineering and Life Science Vol. 1. No. 2 June 2021

Seminar Nasional \& Call Paper Fakultas Sains dan Teknologi (SENASAINS 2nd)

Universitas Muhammadiyah Sidoarjo

6

Tidak

Contohnya departemen yang dimaksud adalah Gudang Bahan Baku dengan Gudang

diharapkan

Packaging. Penempatan kedua departemen ini diharuskan saling berjauhan dikarenakan supaya tidak menggangu porses produksi.

Dari hasil analisa yang terdapat di atas akan menghasilkan departemen mana sajakah yang multak untuk didekatkan, sangat penting, penting, sampai tidak dikehendaki untuk berdekatan.

\section{Total closeness rating (TCR)}

Terbentuknya ARC merupakan dasar untuk dapat melakukan perhitungan selanjutnaya yaitu TCR, yang kemudian digunakan dalam pengalokasian fasilitas. Pada perhitungan TCR akan dilakukan dengan mengonversi nilai setiap derajat kedekatan menjadi nilai rating seperti berikut ini: $\mathrm{A}=5, \mathrm{E}=4, \mathrm{I}=3, \mathrm{O}=2, \mathrm{U}=1$, dan $\mathrm{X}=0$. Departemen yang akan dialokasikan pertamakali merupakan departemen yang memiliki nilai TCR paling terbesar, apabila ada dua departemen dengan nilai TCR yang sama maka yang akan dipilih tingkat kedekatan paling banyak.

Untuk departemen yang akan dialokasikan kedua merupakan departemen yang memiliki tingkat hubungan A pada departemen awal pertama, pada tahap selanjutnya apabila tidak ada hubungan A maka akan diisi dengan departemen yang memiliki tingkat hubungan E, I, O, atau U. Ini dilakukan untuk dapat mempermudah proses pengalokasian departemen. Dari hasil perhitungan TCR telah diketahui departemen mana saja yang memiliki nilai kedekatan tertinggi dengan departemen lain, sehingga akan menjadi main area. Dapat dilihat TCR pada tabel 4.9

Tabel 3.4 Total Closness Rating

\begin{tabular}{|c|c|c|c|c|c|c|c|c|c|c|c|c|c|c|c|c|c|c|c|c|c|c|}
\hline \multirow{3}{*}{ No } & \multirow{3}{*}{ Departemen Kerja } & \multirow{2}{*}{\multicolumn{13}{|c|}{ Departemen Kerja }} & 5 & 4 & 3 & 2 & 1 & $\mathbf{0}$ & \multirow{3}{*}{ TCR } & \multirow{3}{*}{ Order } \\
\hline & & & & & & & & & & & & & & & \multicolumn{6}{|c|}{$\mathbf{X}$} & & \\
\hline & & 1 & 2 & 3 & 4 & 5 & 6 & 7 & 8 & 9 & 10 & 11 & 12 & 13 & $\mathbf{A}$ & $\mathbf{E}$ & $\mathbf{I}$ & $\mathbf{O}$ & $\mathbf{U}$ & $\mathbf{X}$ & & \\
\hline A & Gudang Bahan Baku & - & $\mathrm{A}$ & I & $\mathrm{O}$ & $\mathrm{O}$ & $\mathrm{O}$ & $\mathrm{O}$ & $\mathrm{U}$ & $\mathrm{O}$ & $\mathrm{U}$ & $\mathrm{U}$ & $\mathrm{X}$ & $\mathrm{U}$ & 1 & 0 & 1 & 5 & 4 & 0 & 22 & 8 \\
\hline B & Pengemalan & A & - & $\mathrm{E}$ & I & $\mathrm{E}$ & $\mathrm{O}$ & $\mathrm{O}$ & $\mathrm{U}$ & $\mathrm{U}$ & $\mathrm{U}$ & $\mathrm{U}$ & $\mathrm{U}$ & $\mathrm{U}$ & 1 & 2 & 1 & 2 & 6 & 0 & 26 & 3 \\
\hline $\mathrm{C}$ & Potong kain & I & $\mathrm{E}$ & - & I & A & I & $\mathrm{O}$ & $\mathrm{U}$ & I & $\mathrm{U}$ & $\mathrm{U}$ & $\mathrm{U}$ & $\mathrm{U}$ & 1 & 1 & 4 & 1 & 5 & 0 & 28 & 4 \\
\hline $\mathrm{D}$ & Potong Kerah & $\mathrm{O}$ & $\mathrm{U}$ & $\mathrm{O}$ & - & I & $\mathrm{O}$ & I & $\mathrm{O}$ & $\mathrm{O}$ & $\mathrm{O}$ & $\mathrm{O}$ & I & $\mathrm{U}$ & 0 & 0 & 4 & 5 & 2 & 0 & 24 & 6 \\
\hline $\mathrm{E}$ & $\begin{array}{c}\text { Pengelompokan } \\
\text { Kain }\end{array}$ & $\mathrm{O}$ & $\mathrm{E}$ & A & I & - & $\mathrm{E}$ & I & $\mathrm{E}$ & $\mathrm{E}$ & $\mathrm{O}$ & $\mathrm{O}$ & $\mathrm{U}$ & $\mathrm{U}$ & 1 & 3 & 2 & 4 & 2 & 0 & 33 & 2 \\
\hline $\mathrm{F}$ & Obras Kain & $\mathrm{O}$ & $\mathrm{O}$ & I & $\mathrm{O}$ & $\mathrm{E}$ & - & I & $\mathrm{O}$ & $\mathrm{O}$ & $\mathrm{U}$ & $\mathrm{U}$ & $\mathrm{U}$ & $\mathrm{U}$ & 0 & 1 & 2 & 5 & 4 & 0 & 24 & 7 \\
\hline G & Jahit Kain & $\mathrm{O}$ & $\mathrm{U}$ & $\mathrm{O}$ & I & I & I & - & I & $\mathrm{E}$ & I & $\mathrm{U}$ & $\mathrm{U}$ & $\mathrm{U}$ & 0 & 1 & 5 & 2 & 2 & 0 & 25 & 5 \\
\hline $\mathrm{H}$ & Rak Benang & $\mathrm{U}$ & $\mathrm{U}$ & $\mathrm{U}$ & $\mathrm{O}$ & $\mathrm{O}$ & $\mathrm{O}$ & I & - & A & $\mathrm{U}$ & $\mathrm{U}$ & $\mathrm{U}$ & $\mathrm{U}$ & 1 & 0 & 1 & 3 & 7 & 0 & 21 & 11 \\
\hline I & Bordir & $\mathrm{E}$ & $\mathrm{O}$ & I & $\mathrm{E}$ & $\mathrm{E}$ & $\mathrm{O}$ & $\mathrm{E}$ & $\mathrm{O}$ & - & $\mathrm{U}$ & $\mathrm{U}$ & $\mathrm{U}$ & I & 1 & 4 & 3 & 3 & 3 & 0 & 39 & 1 \\
\hline $\mathrm{J}$ & $\begin{array}{l}\text { Pengeplongan } \\
\text { Kancing }\end{array}$ & $\mathrm{U}$ & $\mathrm{U}$ & $\mathrm{U}$ & $\mathrm{O}$ & $\mathrm{O}$ & $\mathrm{U}$ & I & $\mathrm{U}$ & $\mathrm{U}$ & - & $\mathrm{E}$ & $\mathrm{U}$ & $\mathrm{U}$ & 0 & 0 & 1 & 2 & 8 & 0 & 15 & 13 \\
\hline K & Administrasi & $\mathrm{U}$ & $\mathrm{U}$ & $\mathrm{U}$ & $\mathrm{O}$ & $\mathrm{O}$ & $\mathrm{U}$ & $\mathrm{U}$ & $\mathrm{U}$ & $\mathrm{U}$ & $\mathrm{E}$ & - & A & $\mathrm{U}$ & 1 & 1 & 0 & 2 & 8 & 0 & 21 & 10 \\
\hline M & Setrika \& Packaging & $\mathrm{U}$ & $\mathrm{U}$ & $\mathrm{U}$ & $\mathrm{U}$ & $\mathrm{U}$ & $\mathrm{U}$ & $\mathrm{U}$ & $\mathrm{U}$ & I & $\mathrm{U}$ & $\mathrm{U}$ & $\mathrm{E}$ & - & 0 & 1 & 1 & 0 & 10 & 0 & 17 & 12 \\
\hline
\end{tabular}

Pada tabel 3.4 Total Closness Rating diatas telah menunjukkan bahwa untuk peletakkan departemen pertama didalam Algoritma CORELAP adalah depertemen I (Bordir) yang dikarenakan memiliki nilai TRC paling besar, dan pada peletakkan departemen kedua yaitu E (Pengelompokkan Kain).

\section{Pengolahan data menggunakan algoritma CORELAP}

Pada tabel 3.4 Total Closness Rating di atas telah diketahui bahwa I (Bordir) merupakan departemen yang memiliki nilai TCR paling besar dan akan di letakkan pertama untuk diplotkan. Untuk departemen kedua yang akan diplotkan adalah departemen yang mempunyai nilai TCR tertinggi kedua yaitu E (Departemen Pengelompokkan Kain).

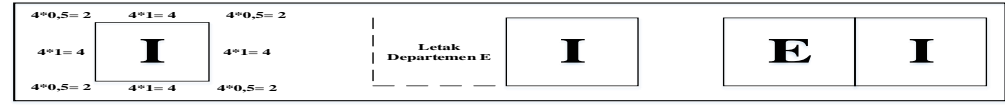

Gambar 3.3 Cara Pengeplotan Departemen Dengan CORELAP

Untuk dapat meletakkan departemen 2 harus ditempatkan disisi kiri yang artinya berlawanan dengan arah jarum jam, dan untuk peletakkan departemen 3 dan departemen selanjutnya akan diplotkan disisi block layout yang memiliki 
Procedia of Engineering and Life Science Vol. 1. No. 2 June 2021

Seminar Nasional \& Call Paper Fakultas Sains dan Teknologi (SENASAINS 2nd)

Universitas Muhammadiyah Sidoarjo

nilai keterkaitan/kedekatan paling besar. Pada gambar 3.3 merupakan cara pengeplotan departemen CORELAP, cara meletakkan dan mengeplotkan departemen I (Bordir) dan Departemen E (Pengelompokkan Kain), yang mana untuk peletakkan (pengeplotan) departemen selanjutnya yaitu departemen B (Pengemalan) dan seterusnya sampai selesai tergantung dari nilai kedekatan (keterkaitan) dan peletakkannya harus berlawanan dengan arah jarum jam.

Dari percobaan ditempatkan (plotkan) yang sudah dilakukan sebanyak empat kali menggunakan Algoritma CORELAP, dan didapatkan hasil penataan layout usulan pada semua departemen seperti pada gambar 3.4 Layout Usulan Untuk Proses Produksi Dengan Analisa CORELAP.

\begin{tabular}{|c|c|c|c|}
\hline A & H & M & J \\
\hline B & E & I & K \\
\hline C & G & D \\
\hline
\end{tabular}

Gambar 3.4 Layout Usulan Untuk Proses Produksi Dengan Analisa CORELAP

Setelah semua departemen telah di plotkan (ditempatkan) dengan Algoritma CORELAP maka pada tahap selanjutnya, akan dilanjutkan dengan pengolahan luas area produksi untuk dapat mengetahui jarak koordinat layout awal dan layout usulan pada lantai produksi.

\section{E. Jarak koordinat}

Dari hasil data Algoritma CORELAP untuk CV. Faris Collections didapatkan untuk jarak koordinat layout awal pada proses produksi adalah sebagai berikut, yang dapat dilihat pada tabel 3.5 Koordinat Layout Awal Produksi.

Tabel 3.5 Koordinat Layout Awal Produksi

\begin{tabular}{|c|c|c|c|c|c|}
\hline Departemen & Kode & Panjang (M) & Lebar (M) & Luas (M2) & Koordinat \\
\hline Gudang Bahan Baku & A & 7 & 4.2 & 29.4 & $(1,1)-(4,7)$ \\
\hline Pengemalan & B & 6 & 3.6 & 21.6 & $(1,8)-(4,13)$ \\
\hline Potong kain & $\mathrm{C}$ & 6 & 3.6 & 21.6 & $(5,8)-(8,13)$ \\
\hline Potong Kerah & $\mathrm{D}$ & 2.7 & 1.2 & 3.24 & $(1,14)-(1,16)$ \\
\hline Pengelompokan Kain & $E$ & 5.4 & 3 & 16.2 & $(4,14)-(6,19)$ \\
\hline Obras Kain & $\mathrm{F}$ & 2.2 & 1.8 & 3.96 & $(9,14)-(10,16)$ \\
\hline Jahit Kain & G & 2.2 & 1.8 & 3.96 & $(9,17)-(10,19)$ \\
\hline Rak Benang & $\mathrm{H}$ & 2 & 0.6 & 1.2 & $(1,17)-(1,18)$ \\
\hline Bordir & I & 13.2 & 4.8 & 63.36 & $(2,25)-(6,38)$ \\
\hline Pengeplongan Kancing & $\mathrm{J}$ & 1.2 & 0.9 & 1.08 & $(9,20)-(9,21)$ \\
\hline Administrasi & $\mathrm{K}$ & 2.8 & 1.2 & 3.36 & $(2,39)-(3,41)$ \\
\hline Gudang Packaging & $\mathrm{L}$ & 3.3 & 2.4 & 7.92 & $(1,21)-(3,24)$ \\
\hline Setrika \& Packaging & $\mathrm{M}$ & 2.3 & 3.3 & 7.59 & $(7,22)-(10,24)$ \\
\hline total & & & & 184.47 & $(1,1)(10,41)$ \\
\hline
\end{tabular}

Dari hasil tabel 3.5 Koordinat Layout Awal Produksi tersebut dapat diketahui hasil dari luas dan jarak koordinat layout awal produksi memiliki total nilai untuk luasnya 184.47 dengan total koordinat keseluruhannya $(1,1)-(10,41)$. Selanjutnya pada hasil Koordinat Layout usulan, didapatkan jarak koordinat layout dengan menggunakan metode Algoritma CORELAP yang dapat dilihat pada tabel 3.6 Koordinat Layout Usulan.

Tabel 3.6 Koordinat Layout Usulan

\begin{tabular}{cccccc}
\hline Departemen & Kode & Panjang $\mathbf{( M )}$ & Lebar (M) & Luas (M2) & Koordinat \\
\hline Gudang Bahan Baku & A & 7 & 4.2 & 29.4 & $(1,1)-(4,7)$ \\
Pengemalan & B & 6 & 3.6 & 21.6 & $(1,8)-(4,13)$ \\
Potong kain & C & 6 & 3.6 & 21.6 & $(1,5)-(8,6)$ \\
Potong Kerah & D & 2.7 & 1.2 & 3.24 & $(4,14)-(4,16)$ \\
Pengelompokan Kain & E & 5.4 & 3 & 16.2 & $(6,7)-(8,12)$ \\
Obras Kain & F & 2.2 & 1.8 & 3.96 & $(7,16)-(8,18)$ \\
Jahit Kain & G & 2.2 & 1.8 & 3.96 & $(7,13)-(8,15)$ \\
Rak Benang & H & 2 & 0.6 & 1.2 & $(7,19)-(8,19)$ \\
Bordir & I & 13.2 & 4.8 & 63.36 & $(2,22)-(6,35)$ \\
Pengeplongan Kancing & J & 1.2 & 0.9 & 1.08 & $(7,20)-(8,20)$ \\
Administrasi & K & 2.8 & 1.2 & 3.36 & $(2,36)-(3,38)$
\end{tabular}


Procedia of Engineering and Life Science Vol. 1. No. 2 June 2021

Seminar Nasional \& Call Paper Fakultas Sains dan Teknologi (SENASAINS 2nd)

Universitas Muhammadiyah Sidoarjo

$\begin{array}{cccccc}\text { Gudang Packaging } & \mathrm{L} & 3.3 & 2.4 & 7.92 & (1,18)-(3,21) \\ \text { Setrika \& Packaging } & \mathrm{M} & 2.3 & 3.3 & 7.59 & (1,14)-(3,17) \\ \text { Total } & & & & 184.47 & (1,1)(8,38)\end{array}$

Dari hasil tabel 3.6 dapat diketahui untuk nilai luas dan jarak koordinat layout usulan memiliki nilai total luasnya adalah 184.47 dengan total koordinat $(1,1)-(8,38)$. Dengan hasil ini untuk jarak koordinat layout awal dan layout usulan pada jarak koordinatnya selanjutnya akan dimasukkan ke dalam Software WinQSB.

\section{F. Penentuan efesiensi layout usulan menggunakan total momen}

Hasil dari jarak koordinat pada tiap-tiap departemen pada layout awal dan juga koordinat layout usulan tersebut, selanjutnya akan dimasukkan dalam Software WinQSB, Untuk dapat mengetahui dan menentukan indikator yang seberapa baik dalam sebuah layout dengan cara membandingkan total momen tersebut.

Total momen juga menjadi salah satu tujuan dari Algoritma CORELAP, untuk dapat meminimasi perpindahan barang (total momen) pada CV. Faris Collections. Berikut ini adalah total momen dari layout awal dan layout usulan seperti tabel 3.7 Total Momen Layout.

Tabel 3.7 Total Momen Layout

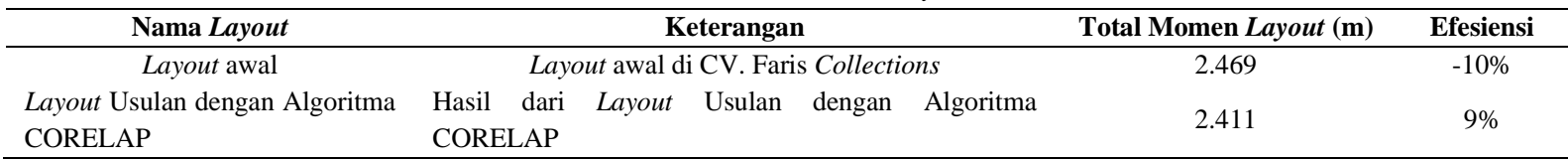

Dari hasil perhitungan menggunakan WinQsb diketahui total momen pada tabel 4.12 Total Momen Layout diatas, pada untuk layout awal mendapatkan total momen sebesar 2.469 dan untuk layout usulan mendapatkan total momen sebesar 2.411 yang dapat dilihat pada lampiran 4 dan 5. Setelah mengetahui total momen tersebut selajutnya akan digunakan untuk mengetahui tingkat efesiensi pada layout awal dan layout usulan. Dengan rumus seperti berikut ini:

$$
\begin{gathered}
=\frac{2.469 \times 100}{2.411}=109,8714-100=-10 \% \\
\quad \text { Sumber: Rosyadi } 2018
\end{gathered}
$$

Dari hasil tersebut untuk efesiensi pada layout awal didapatkan hasil sebesar - $10 \%$ dan untuk hasil layout usulan sebesar 9\%, maka dari hasil tersebut dapat diartikan dari analisa layout dengan menggunakan Algoritma CORELAP mampu mengurangi total momen perpindahan dan meningkatkan efesiensi sebasar $9 \%$ dari kondisi layout awal pada CV. Faris Collections.

Dari hasil analisa Algoritma CORELAP juga menghasilkan jarak departemen yang lebih sedikit / dekat, jarak yang telah dihasilkan ini sangat mempengaruhi total momen perpindahan pada departemen satu dan juga departemen lainnya. Berikut ini merupakan perubahan departemen dan juga jarak pada setiap departemen seperti tabel 3.8 Perubahan Jarak Antar Departemen.

Tabel 3.8 Perubahan Jarak Antar Departemen.

\begin{tabular}{clc}
\hline Kode & \multicolumn{1}{c}{ Departemen } & Jarak (M) \\
\hline A-B & $\begin{array}{l}\text { Proses inspeksi pemilihan kain roll yang akan di desain sesuai dengan permintaan konsumen } \\
\text { B-C }\end{array}$ & $\begin{array}{l}\text { Setelah proses desain kain lalu akan dilanjutkan dengan proses potong kain yang sesuai desain } \\
\text { yang telah diukur }\end{array}$ \\
C-D & $\begin{array}{l}\text { Setelah pemotongan kain lalu memerlukan potongan kerah untuk bagian atas kemeja } \\
\text { D-E }\end{array}$ & Setelah pemotongan kerah selesai, lalu melakukan penyortiran untuk mempermudah \\
pengelompompokkan pada tiap-tiap bagian & 3 \\
E-F & Setelah melakukan inspeksi dan pengelompokan pada setiap bagain lalu akan dilakukan obras & 1.2 \\
F-G & Proses obras lalu aka menuju proses jahit kain untuk dapat menyatukan tiap bagian & 1 \\
G-H & Untuk memilih penggunaan benang jahit yang cocok dengan bagian tepi kain & 1 \\
H-I & Pemilihan benang berdasarkan desain dan warna yang diperlukan & 4 \\
I-J & Setalah pakaian telah dibordir akan dilajutkan dengan pengeplongan kain untuk kancing & 3.3
\end{tabular}


Procedia of Engineering and Life Science Vol. 1. No. 2 June 2021

Seminar Nasional \& Call Paper Fakultas Sains dan Teknologi (SENASAINS 2 ${ }^{\text {nd }}$ )

Universitas Muhammadiyah Sidoarjo

J-K Setalah pengeplongan selesai menginfokan pada administrasi bahwa pakaian akan segera selesai

K-L Administrasi memberikan tanda yang berupa alamat dan tempat pada setiap pakaian yang telah selesai

L-M Sebelum pakaian dimasukkan digudang packaging terlebih dahulu disetrikan dan dikemas

Terdapat perubahan jarak pada kedekatan tiap - tiap departemen yang dapat dilihat pada tabel 3.2 Jarak Kedekatan Antar Departemen Lantai dan Tabel 3.8 Perubahan Jarak Antar Departemen, untuk jarak awalnya 40.1 meter menjadi 32,6 meter. Efesiensi perubahan jarak pada layout awal dan layout usulan menggunakan Algoritama CORELAP sebesar 18\%. Dan menghasilkan usulan layout seperti pada gambar 3.5.

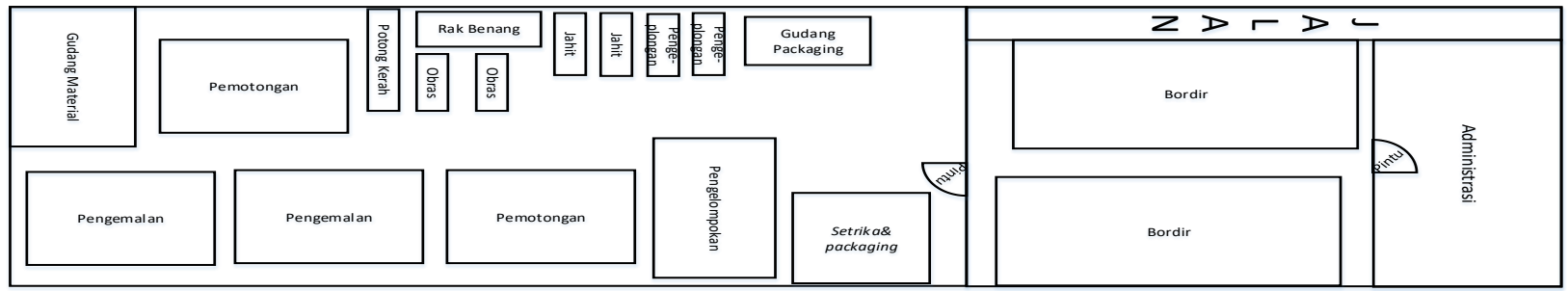

Gambar 3.5 Usulan Layout Cv. Faris Collections

\section{KESIMPULAN DAN SARAN}

\section{A. Kesimpulan}

Berikut ini kesimpulan yang didapat pada penelitian ini dengan menggunakan Algoritma CORELAP adalah sebagai berikut: (1) Penentuan layout pada sebuah perusahaan merupakan hal utama untuk menempatkan tiap - tiap departemen. Untuk usulan layout yang diusulkan adalah hasil dari metode Algoritma CORELAP. Dari hasil total momen layout usulan yang hasinyal lebih rendah dapat memberikan rancangan perbaikan layout pada CV. Faris Collections. (2) Penigkatan tingkat efesiensi ini merupakan hasil dari total momen layout awal dengan total momen layout usulan, dan peningkatan tingkat efesiensi pada Algoritma CORELAP sebesar 9\%. Dan untuk efesiensi pada perubahan antar jarak departemen pada layout awal dan layout usulan sebesar 18\%. (3) Dari hasil analisa menggunakan Total Closeness Rating dan Algoritma CORELAP pada CV. Faris Collections, bahwa perlunya perbaikan pada layout untuk dapat meningkatkan produktivitas agar pengerjaan proses semakin produktif dan efektif.

\section{B. Saran}

Pada penelitian ini hanya menggunakan 2 metode saja, diharapkan pada penelitian selanjutnya dapat menggunakan beberapa penggunaan metode lain untuk sebagai pembanding pada penelitian ini. Penelitian tersebut diharapkan mampu untuk dapat membantu perusahaan dalam melakukan perbaikan layout.

\section{REFERENSI}

[1] Adi Sukarno Rachman, 2018."Peramalan Produksi Gula Menggunakan Metode Jaringan Syaraf Tiruan Backpropagation Pada PG Candi Baru Sidoarjo". Malang. Universitas Brawijaya. Fakultas Ilmu Komputer. Teknik Informatika. Vol. 2. No. 2. Halaman 1683-1689.

[2] Evi Kumalasari, 2018. Activity Relationship Chart Sebagai Perancangan Tata Letak Fasilitas Miniplant Pada Produksi Chips Porang Di Desa Jembul. Mojokerto. Universitas Majapahit. Halaman 83 - 88.

[3] Moh, Ririn Rosyadi, 2018. Analisa Tata Letak Fasilitas Produksi Dengan Metode Arc, Ard, Dan Aad Di Pt. Xyz. Gresik. Sekolah Tinggi Teknik Qomaruddin Gresik. Fakultas Teknik. Teknik Industri. Vol. 16. No. 1. Halaman 82-95. 
Procedia of Engineering and Life Science Vol. 1. No. 2 June 2021

Seminar Nasional \& Call Paper Fakultas Sains dan Teknologi (SENASAINS 2nd)

Universitas Muhammadiyah Sidoarjo

[4] Rio Wirawan Nicholas, 2018."Usulan Perancangan Ulang Tata Letak Lantai Produksi untuk Memaksimalkan Area Produksi (Studi Kasus PT. XYZ). Banten. Universitas Unika Atma Jaya Jakarta. Teknik Industri. Jurnal Metris ISSN 1411-3287.

[5] Ukarta Taringan, 2019.’Perancangan Ulang dan Simulasi Tata Letak Fasilitas Produksi Gripper Rubber Seal dengan Menggunakan Algoritma Corelap, Aldep, dan Flexsim". Sumatra. Universitas Sumatra Utara. Fakultas Teknik. Teknik Industri. Vol. 21. No. 1. Halaman 74-84.

[6] Wresni Anggraini, 2017."Perancangan Ulang Tata Letak Fasilitas Di Pabrik Karet P\&P Bangkinang Untuk Optimalisasi Jarak dan Ongkos Material Handling". Pekan Baru. Universitas Indonesia Suska Riau. Fakultas Sains dan Teknologi. Jurusan Teknik Industri. ISSN 2579-5400. Halaman 546-554. 